\title{
Konstrukční výzkum ve vzdělávání
}

\author{
Eva Ellederová \\ Masarykova univerzita, Pedagogická fakulta, Institut výzkumu školního vzdělávání
}

Redakci zasláno 9. 3. 2017 / upravená verze obdržena 8. 6.2017 /

k uveřejnění přijato 8. 6. 2017

\begin{abstract}
Abstrakt: Cílem této studie je vymezit pojetí konstrukčního výzkumu ve vzdělávání jako výzkumného designu, který klade důraz na vývoj řešení komplexních problémů v pedagogické praxi a na vývoj či validaci teorií o vzdělávacích procesech a vzdělávacích prostředích. Pro objasnění významu konstrukčního výzkumu je vymezena jeho otevřená a intervenční povaha a dualistický přínos. Následně se pokoušíme zmapovat samotný vznik, vývoj a současný stav konstrukčního výzkumu ve vzdělávání, který na začátku 21. století zahájil novou etapu praktické výzkumné metodologie vedoucí k účinnému překlenutí propasti mezi výzkumem a praxí ve formálním vzdělávání. Studie umožňuje porovnat zastoupení konstrukčního výzkumu ve vybraných zemích, oblastech vzdělávání a typech intervencí. Těžištěm je přehledová studie realizovaných konstrukčních výzkumů, které se zaměřují převážně na design učebních materiálů a výuku jazyků. Na základě analýzy empirických studií diskutujeme důležité faktory a doporučení z ní vyplývající a představující teoretická a metodologická východiska pro námi zamýšlený konstrukční výzkum učebnice pro výuku angličtiny pro specifické účely.
\end{abstract}

Klíčová slova: konstrukční výzkum, intervence, iterace, experimentální výzkum, akční výzkum, dualistický charakter konstrukčního výzkumu, validační a vývojové studie, procesní a hmotné konstrukční principy

Tato studie představuje problematiku konstrukčního výzkumu jako relativně nového výzkumného přístupu $\mathrm{v}$ pedagogickém výzkumu, jenž by mohl účinně překlenout propast mezi výzkumem a praxî́ ve formálním vzdělávání. Prostřednictvím konstrukčního výzkumu se vyvíjí partnerství mezi výzkumníky a praktiky zajišt’ující spolupráci na výzkumu od počáteční identifikace problému přes literární rešerše až po návrh intervence ${ }^{2}$, design,

1 Aristoteles odlišuje praxis, která je průběhová (jejím cílem je sama činnost), od poiesis, která je produktová (jejím cílem je produkt) (Višňovský et al., 2012, s. 309). Z této koncepce vychází konstrukční výzkum, jehož hlavním přínosem je produkce procesních a hmotných konstrukčních principů.

2 Intervence je v konstrukčním výzkumu chápána jako jakýkoli fenomén (vzdělávací program, vzdělávací prostředí, výuková metoda, učební materiál atd.), jenž může být navržen a následně se v průběhu výzkumu vyvíjí.

https://doi.org/10.5817/PedOr2017-3-419 
implementaci, evaluaci a publikaci konstrukčních principů. Tento typ výzkumu rovněž souvisí s praktickým obratem $\mathrm{v}$ socio-humanitních vědách, který představují Višňovský, Kaščák a Pupala (2012). Ve své studii řeší otázky vztahu teorie a praxe v učitelské profesi a následně formulují koncept reflektujícího praktika, jehož hlavní myšlenkou je, že praktik vyvozuje nebo produkuje teoretické poznání na základě vlastní praxe, a tím se stává automatickou pojistkou úspěšné validace teorie prostřednictvím osobní zkušenosti (Višňovský et al., 2012, s. 327). Takový druh komunikace mezi vědou a praxí má na učitele dvojí vliv - na každodenní vykonávání učitelské profese v kontaktu se žáky a na vytváření vlastní profesní identity.

Potřeba výzkumného designu, který bude relevantně řešit problémy $\mathrm{v}$ pedagogické praxi a jenž bude vyvíjet návrhy, které budou ověřovány $\mathrm{v}$ praxi a zakotveny $\mathrm{v}$ pedagogických vědách, je stále předmětem mnoha diskuzí mezi výzkumníky z různých oblastí vzdělávání. Design-Based Research Collective uvádí, že pedagogický výzkum „je často oddělen od problémů a otázek každodenní praxe - nesoulad, který vede k potřebě nových výzkumných přístupů, které oslovují problémy praxe prrímo a vedou k vývoji ,využitelných poznatkư' $(2003$, s. 5). Konstrukční výzkum se tak postupně stal nově vznikajícím paradigmatem pro studium vzdělávání v kontextu školy či třídy prostřednictvím systematického navrhování a analýzy vzdělávacích strategií a nástrojů. Van der Akker (2006, s. 5) zdůrazňuje, že „hodnota konstrukčního výzkumu je měřena svojí praktičností pro uživatele ve skutečných kontextech“, a doplňuje, že „konstrukční výzkum je (alespoň z části) založen na teoretických poznatcích, a testování designu v praxi přispívá $\mathrm{k}$ vytváření teorie." Větší pozornost je věnována procesům výběru a zpracování výzkumných nálezů, které jsou pro praktiky relevantní, vývoji na nich založených modelů učení a vyučování, případně konkrétních produktů. Systematické šíření těchto inovací zvyšuje pravděpodobnost, že praktici využijí výsledky konstrukčního výzkumu a přispějí ke zvyšování kvality výuky.

Následující kapitoly představují teoretická východiska k námi zamýšlenému výzkumnému projektu konstrukčního výzkumu učebnice pro výuku angličtiny pro specifické účely (dále jen $E P^{3}$ ). Primárním cílem je propojení tvorby učebnice s následnou iterací - implementací této učebnice do výuky za účelem evaluace návrhu a re-designu tak, aby učebnice

$3 \quad$ Z anglického English for Specific Purposes. 
co nejlépe vyhovovala jako vyučovací a učební prostředek pro cílovou skupinu studentů4, a za současného kritického rozvíjení teorie tvorby a hodnocení učebnic.

Cílem této studie je vymezit koncept konstrukčního výzkumu ve vzdělávání, zmapovat dosavadní stav poznání $v$ oblasti konstrukčního výzkumu zaměřeného na design učebních materiálů a výuku cizích jazyků a následně diskutovat důležité faktory včetně doporučení, které z analyzovaných empirických studií vyplývají, a odhalit „bílá místa“, která budou představovat teoretická a metodologická východiska pro náš výzkumný záměr.

\section{Upřesnění terminologie}

Po dobu své existence byl konstrukční výzkum označován mnoha různými termíny. Anglický termín design zde znamená návrh nebo konstrukci. Mezi některá z nejčastějších označení patří design experiments (Brown, 1992; Cobb et al., 2003; Collins, 1990), formative research (Newman, 1990), developmental research (Lijnse, 2010), design-based research (Amiel \& Reeves, 2008; Anderson \& Shattuck, 2011; Bakker \& Van Eerde, 2013; Barab \& Squire, 2004; Pardo-Ballester \& Rodríguez, 2010; Štemberger \& Cencič, 2014) a educational design research (Hogue, 2013; Plomp \& Nieveen, 2007, 2013a, 2013b; Van der Akker, 2006). Reeves, McKenneyová a Herrington (2011) zdůvodňují používání posledního zmíněného termínu ze tří důvodů:

1) termín design research se používá výzkumníky v oborech výpočetní techniky a průmyslové výroby a přívlastek educational umožňuje odlišit tento výzkumný prrístup od přístupů v jiných oborech;

2) ačkoli má termín design-based research mnoho stoupenců, zdá se, že př́íliš zdůrazňuje ve výzkumném př́ístupu hledisko designu;

3) dvě přední publikace zabývající se konstrukčním výzkumem (Kelly, Lesh, \& Baek, 2008; Van der Akker, 2006) nepoužívají termín design-based research.

Trna (2011, s. 7) uvádí, že z důvodu dosavadního využití různých českých synonym byl pro překlad design zvolen termín konstrukce (konstrukční).

4 Ve studii se několikrát vyskytuje termín žák a student. Termín student uvádíme vždy ve vztahu k našemu konstrukčnímu výzkumu, který bude realizován na výzkumném vzorku sestávajícím ze studentů vysoké školy a rovněž v případě popisu výzkumů realizovaných na vysokých školách. V ostatních případech používáme termín žák. 
Podstatou konstrukčního výzkumu ve vzdělávání je tedy konstrukce neboli tvorba nového produktu (kurikula, výukových metod, učebních materiálů apod.) prostřednictvím jeho přepracování a zkvalitnění tak, aby se vyřešily stávající problémy a aby výsledek co nejlépe vyhovoval teoretickým i praktickým požadavkům výchovně-vzdělávacího procesu. Na základě uvedených důvodů se přikláníme k používání termínu konstrukční výzkum ve vzdělávání, který s ohledem na zřejmý kontext této studie zkracujeme na termín konstrukční výzkum.

\section{Vymezení problematiky konstrukčního výzkumu ve vzdělávání}

\subsection{Konstrukční, experimentální a akční výzkum}

Konstrukční výzkum předpokládá zavedení inovace do vzdělávání stejně jako experimentální výzkum a akční výzkum. Štembergerová a Cencičová (2014) diskutují podobnosti a rozdíly v základních charakteristikách těchto tří typů výzkumu (viz tabulka 1). Jedním společným znakem konstrukčního a experimentálního výzkumu je zavedení inovace a následné testování efektivity a prospěšnosti. Nicméně cílem experimentálního výzkumu je výhradně testování efektivity inovace, a ne zdokonalení praxe a obohacení teorie, jak je tomu v př́padě konstrukčního výzkumu. Experimentální výzkum nepředpokládá úzkou spolupráci mezi výzkumníky, praktiky a autory inovace a je typický svým lineárním výzkumným procesem, který neposkytuje možnost znovuzavedení nebo zdokonalení. Obvykle je zakončen interpretací výsledků a potvrzením nebo vyvrácením hypotéz.

Z tabulky 1 je zřejmé, že akční výzkum a konstrukční výzkum sdílejí podobné charakteristiky a pro praktiky a výzkumníky mohou být obtížně rozlišitelné. Vyplývá to ze skutečnosti, že mají společná epistemologická, ontologická a metodologická východiska a oba typy výzkumu jsou pragmatické a aplikační (Anderson \& Shattuck, 2011). Pro oba, konstrukční i akční výzkum, je typický cyklický výzkumný proces s několika iteracemi, zaměření na zdokonalování praxe, spolupráci mezi výzkumníky a praktiky, kombinovaný metodologický př́ístup a profesní vývoj realizátorů. Oba výzkumy také spočívají v otevřeném a intervenčním přístupu (Bakker \& Van Eerde, 2013).

Mezi konstrukčním a akčním výzkumem existují následující rozdíly (Štemberger \& Cencič, 2014, s. 70): 
- Konstrukční výzkum se zaměřuje na vývoj principů inovačního designu, který by měl nejen vyhovovat místním potřebám nebo potřebám praxe, ale měl by přispět $\mathrm{k}$ teoretickým a vědeckým zjištěním, tzn. objevování, zkoumání a potvrzování teoretických souvislostí.

- Iniciativa pro akční výzkum obvykle vychází od praktiků a akční výzkum je realizován osobou, která si přeje zdokonalit svoji vlastní praxi, zatímco iniciativa pro konstrukční výzkum vychází z výzkumníků nebo inovačních návrhářù (např. učební pomůcka, nový program atd.).

- Akční výzkum je na rozdíl od konstrukčního výzkumu obvykle realizován samotnými učiteli, kteří nevyužívají expertizy a znalostí výzkumníků a ani s nimi nespolupracují v týmu.

Tabulka 1

Srovnání konstrukčního, experimentálního a akčního výzkumu

\begin{tabular}{|c|c|c|c|}
\hline & Konstrukční & Experimentální & Akční \\
\hline $\begin{array}{l}\text { Výzkumný } \\
\text { proces }\end{array}$ & $\begin{array}{l}\text { Cyklický, několik iterací, } \\
\text { flexibilní }\end{array}$ & Lineární, jednosměrný & $\begin{array}{l}\text { Cyklický, několik } \\
\text { iterací, flexibilní }\end{array}$ \\
\hline $\begin{array}{l}\text { Výzkumné } \\
\text { paradigma }\end{array}$ & $\begin{array}{c}\text { Kombinované: } \\
\text { kvalitativní } \\
\text { (pozitivistické) } \\
\text { a kvantitativní } \\
\text { (interpretativní) } \\
\end{array}$ & Kvantitativní & $\begin{array}{c}\text { Většinou kvalitativní } \\
\text { nebo kombinované } \\
\text { s kvantitativním }\end{array}$ \\
\hline $\begin{array}{c}\text { Iniciátor/vedoucí } \\
\text { výzkumu }\end{array}$ & $\begin{array}{c}\text { Výzkumníci ve spolupráci } \\
\text { s praktiky a techniky }\end{array}$ & $\begin{array}{l}\text { Výzkumník/ } \\
\text { výzkumníci }\end{array}$ & Praktici \\
\hline Výzkumný cíl & $\begin{array}{l}\text { Zdokonalení praxe, } \\
\text { obohacení teorie }\end{array}$ & $\begin{array}{l}\text { Testování efektivity } \\
\text { inovace }\end{array}$ & Zdokonalení praxe \\
\hline Inovace & $\begin{array}{l}\text { Navržená předem } \\
\text { a zdokonalená během } \\
\text { výzkumného procesu }\end{array}$ & $\begin{array}{l}\text { Testuje se efektivita již } \\
\text { navržené inovace }\end{array}$ & $\begin{array}{c}\text { Navržená } \\
\text { a zdokonalená } \\
\text { během výzkumného } \\
\text { procesu }\end{array}$ \\
\hline Metody sběru dat & $\begin{array}{l}\text { Kvantitativní } \\
\text { a kvalitativní } \\
\text { (např. pozorování, } \\
\text { rozhovor, testování } \\
\text { znalostí apod.) }\end{array}$ & $\begin{array}{l}\text { Kvantitativní } \\
\text { (napřs. testování } \\
\text { znalostí, měření } \\
\text { postojů škálováním, } \\
\text { ratingové metody) }\end{array}$ & $\begin{array}{c}\text { Většinou kvalitativní } \\
\text { (napřs pozorování, } \\
\text { rozhovor) }\end{array}$ \\
\hline $\begin{array}{c}\text { Metody } \\
\text { zpracování } \\
\text { a analýzy dat }\end{array}$ & $\begin{array}{l}\text { Kvalitativní } \\
\text { a kvantitativní } \\
\text { (statistické) }\end{array}$ & $\begin{array}{c}\text { Kvantitativní } \\
\text { (statistické) }\end{array}$ & Většinou kvalitativní \\
\hline
\end{tabular}

Pozn.: Upraveno podle Štembergerové a Cencičové (2014, s. 69). 


\subsection{Otevřená a intervenční povaha konstrukčního výzkumu}

Jedním ze způsobů, jakým je možné charakterizovat konstrukční výzkum, je porovnat ho s jinými výzkumnými designy na základě dvou následujících dimenzí: naturalistické vs. intervenční a otevřené vs. uzavřené (Bakker \& Van Eerde, 2013). Tabulka 2 znázorňuje postavení přístupů konstrukčního výzkumu. Naturalistický př́stup umožňuje analyzovat, jak vzdělávání probíhá bez zásahu výzkumníka - např. prostřednictvím školní etnografie a dotazníkových šetření. Intervenční přístup spočívá v zasahování, intervenci do toho, co se přirozeně odehrává. Výzkumníci záměrně manipulují s podmínkami vzdělávání nebo vyučují podle specifických metod (např. problémové vyučování). Takový výzkum je nezbytný, pokud se typ vzdělávání, který výzkumníci chtějí zkoumat, neodehrává v přirozeném prostředí. Př́klady intervenčních přístupů jsou experimentální výzkum, akční výzkum a konstrukční výzkum.

Výzkumné př́stupy také mohou být více otevřené nebo uzavřené. Otevřený př́stup výzkumu spočívá v nízké kontrole situace nebo dat, kdy je velmi obtížné situaci nebo data kontrolovat a vyhodnocovat. Př́íkladem jsou otevřené otázky v dotazníku, které umožňují specifikovat názor respondentů. Naproti tomu uzavřený př́stup spočívá ve vysoké kontrole situace nebo omezeném počtu možností. Příkladem jsou uzavřené otázky v dotazníku s volbou jedné správné odpovědi, které zjednodušují kódování a celkové zpracování dat. Dotazníky s uzavřenými odpověd'mi nebo Likertova škála, umožňující zjistit nejen obsah postoje, ale i jeho přibližnou sílu, jsou př́klady uzavřenějšího přístupu než polostrukturované rozhovory. Podobně experiment porovnávající dvě podmínky je uzavřenější než konstrukční výzkum, ve kterém se učební materiály nebo metody výuky postupně vyvíjí a přizpůsobují se podmínkám, ve kterých výzkum probíhá.

Tabulka 2

Otevřená a intervenční povaha konstrukčního výzkumu

\begin{tabular}{ccc}
\hline & Naturalistický & Intervenční \\
\hline Uzavřený & $\begin{array}{c}\text { Dotazníkové šetření s uzavřenými } \\
\text { otázkami }\end{array}$ & Experiment \\
Otevřený & $\begin{array}{c}\text { Rozhovory s otevřenými otázkami } \\
\text { Školní etnografie }\end{array}$ & $\begin{array}{c}\text { Akční výzkum } \\
\text { Konstrukční výzkum }\end{array}$ \\
\hline
\end{tabular}

Pozn.: Převzato z Bakkera a Van Eerdeové (2013, s. 7). 


\subsection{Dualistický charakter konstrukčního výzkumu}

Konstrukční výzkum byl vyvinut jako způsob provádění formativního výzkumu pro testování vzdělávacích designů založených na teoretických principech odvozených z předcházejícího výzkumu. Tento př́ístup spočívá v postupném zdokonalení designu prostřednictvím zavádění prvotního designu do praxe a sledování, jak funguje (Collins, Joseph, \& Bielaczyc, 2004, s. 18-19). Následně je design na základě zkušeností tak dlouho upravován, dokud nejsou závady odstraněny. Zkoumáním designu $\mathrm{v}$ praxi za účelem postupného zdokonalování je v průběhu času možné vyvinout dokonalejší design, jehož systematická evaluace současně vede k rozvoji a obohacení stávající teorie.

Plomp a Nieveenová (2013a, s. 16) uvádí, že můžeme rozlišit dva typy studií v závislosti na účelu konstrukčního výzkumu: vývojové studie a validační studie. $\mathrm{V}$ př́padě vývojových studií (development studies) je výchozím bodem identifikace vzdělávacího problému, pro který nejsou k dispozici žádné validační principy, na jejichž základě mohou být design a vývojové aktivity konstruovány, nebo jich existuje jen velmi málo. Tento typ konstrukčního výzkumu je definován jako „systematická studie designu, vývoje a evaluace vzdělávacích intervencí (napřs. programů, strategií učení a vyučování, učebních materiálů, produktů a systémů) v jejich cílových kontextech $\mathrm{s}$ cílem řešit komplexní problémy pedagogické praxe a prohlubovat znalosti o charakteristikách těchto intervencí a procesu jejich designu a vývoje" (Plomp \& Nieveen, 2013a, s. 23). Vývojové studie integrují nové poznatky z předchozího výzkumu do výzkumného procesu a vylepšují vzdělávací inovace založené na pilotním zavádění designu do praxe. Van der Akker (2006, s. 153) rozlišuje u vývojových studií dva hlavní typy konstrukčních principů:

1) procesní konstrukční principy: charakteristika výzkumného přístupu;

2) hmotné konstrukční principy: charakteristika designu samotného.

$\mathrm{V}$ př́ípadě validačních studií (validation studies) je účelem konstrukčního výzkumu vývoj nebo validace teorie. Tento druh konstrukčního výzkumu je definován jako systematická studie designu, vývoje a evaluace vzdělávacích intervencí (např. procesů učení, vzdělávacího prostředí apod.) s cílem vyvíjet nebo validovat teorie (Plomp \& Nieveen, 2013a, s. 25). Validační studie se zaměřují na design vzdělávacích prostředí nebo procesů s cílem vyvinout a validovat teorie o vzdělávacím procesu a o designu vzdělávacích prostředí. Validační studie se podle Gravemeijera a Cobba (cit. podle Van der Akker, 2006, s. 231) zaměřují na rozvoj teorií učení a vyučování na následujících úrovních: 
- mikro-teorie - na úrovni vyučovacích aktivit;

- místní instrukční teorie - na úrovni pořadí a organizace vyučovacích aktivit;

- oborově specifické instrukční teorie: na úrovni obsahu pedagogických znalostí.

Výzkumníci nepracují v laboratorních nebo simulovaných prostředích, ale volí si přirozené prostředí třídy jako „zkušebního zařízení“. Jednotlivé fáze validačních studií jsou (Gravemeijer \& Cobb, cit. podle Van der Akker, 2006, s. 231):

- př́prava prostředí - rozpracování předběžného instrukčního designu založeného na interpretačním rámci;

- experiment ve třídě - testování a zdokonalování instrukčního designu nebo místní instrukční teorie a rozvoj porozumění tomu, jak funguje;

- retrospektivní analýza - studium celého datového souboru za účelem přispění k rozvoji místní instrukční teorie a (zdokonalení) interpretačního rámce.

Je ovšem důležité mít na paměti, že přílišné zaměření se na realizaci výzkumů za účelem vývoje oborově specifických vzdělávacích teorií může časem proces konstrukčního výzkumu do určité míry narušit. DiSessa a Cobb (2004, s. 83) upozorňují, že ačkoli takové teorie vycházejí z opakovaných cyklů designu a analýzy, analýzy jsou realizovány prostřednictvím zavedených teoretických konstruktů. $\mathrm{Z}$ toho důvodu nám přílišné soustředění se na vývoj oborově specifických vzdělávacích teorií neumožní důkladně prozkoumat a lépe pochopit komplexnost a rozmanitost prostředí, ve kterém výzkum provádíme.

Příslušný přínos konstrukčního výzkumu (viz tabulka 3) - kromě využitelné a účinné intervence - tedy spočívá v rozšíření souboru poznatkủ $v$ oblasti vzdělávání. Jinými slovy, jeho výzvou (Plomp \& Nieveen, 2013a, s. 22) je „zachytit a jasně formulovat implicitní rozhodnutí související s konstrukčním procesem a přetransformovat je do zásad pro řešení vzdělávacích problémů“. Proto je v procesu konstrukčního výzkumu nutné vyvíjet a aplikovat předpoklady ve formě soudržného souboru vzájemně souvisejících fází designu, které např́íklad Van der Akker (2006, s. 33) popisuje následným způsobem: 
„Abychom v dané situaci S dosáhli kroku C, je nutné provést krok A." Tento zřetel se týká teoretické orientace konstrukčního výzkumu jako jedné $\mathrm{z}$ jeho charakteristik.

Dualistický př́nos konstrukčního výzkumu, jmenovitě intervence a poznatky nebo teorie z výzkumu vyplývající, je jednou z jeho základních charakteristik. Je důležité si uvědomit, že konstrukční výzkum zahrnuje systematické vzdělávací konstrukční procesy, ale ne všechny systematické vzdělávací konstrukční procesy mohou být nazývány výzkumem. Svým cílem přispět $\mathrm{k}$ souboru vědeckých poznatků ( $\mathrm{v}$ př́ípadě vývojové studie) nebo vytvořit či validovat teorie (v př́ípadě validační studie) se konstrukční výzkum odlišuje od systematických vzdělávacích konstrukčních procesů zaměřujících se pouze na tvorbu vzdělávacích materiálů prostřednictvím iterativních cyklů testování a zdokonalování prototypů bez propojení s testováním a vývojem teorie, což potvrzují i Bakker a Van Eerdeová (2013, s. 3): „V̌̌tšina intervenčních výzkumných přístupů spočívá v jednoznačném oddělení konstrukce a testování." Amiel a Reeves (2008, s. 34) uvádí tři klíčové charakteristiky výzkumného rámce konstrukčního vývoje:

- řeší komplexní problémy ve skutečných kontextech ve spolupráci s praktiky;

- integruje známé a hypotetické konstrukční principy prostřednictvím technologického vývoje designu s cílem poskytnout přesvědčivá řešení těchto komplexních problémů;

- uskutečňuje důkladný a promyšlený průzkum za účelem ověřovat a zlepšovat inovativní vzdělávací prostředí a také definovat nové konstrukční principy.

Z výše uvedeného vyplývá, že metodologie konstrukčního výzkumu nejen umožňuje učitelům systematickou reflexi výuky, ale současně také podporuje jejich rozvoj didaktických znalostí obsahu. ${ }^{5}$

5 Didaktické znalosti obsahu (z anglického pedagogical content knowledge) jsou specifické znalosti, které spočívají v učitelově schopnosti transformovat obsah „do forem, které jsou pedagogicky účinné, a přesto přizpůsobivé schopnostem žáků“ (Shulman,1987, s. 15). 
Tabulka 3

Dualistický př́nos konstrukčního výzkumu

\begin{tabular}{|c|c|c|c|c|}
\hline $\begin{array}{c}\text { Typ } \\
\text { studií }\end{array}$ & $\begin{array}{l}\text { Výzkumný } \\
\text { cíl } \\
\end{array}$ & $\begin{array}{c}\text { Ohnisko } \\
\text { kvality }\end{array}$ & $\begin{array}{c}\text { Metodologický } \\
\text { důraz } \\
\end{array}$ & $\begin{array}{c}\text { Dualistický } \\
\text { přínos }\end{array}$ \\
\hline Vývojová & $\begin{array}{l}\text { Vývoj } \\
\text { intervence: } \\
\text { řešit } \\
\text { vzdělávací } \\
\text { problémy }\end{array}$ & $\begin{array}{c}\text { Praktický } \\
\text { aspekt } \\
\text { intervence }\end{array}$ & $\begin{array}{l}\text { Iterativní vývoj } \\
\text { s formativní } \\
\text { evaluací } \\
\text { v různých } \\
\text { uživatelských } \\
\text { prostředích } \\
\end{array}$ & $\begin{array}{c}\text { 1) Vývoj výzkumných } \\
\text { intervencí jako řešení } \\
\text { komplexních problémů } a \\
\text { 2) produkce (opakovaně } \\
\text { použitelných) konstrukčních } \\
\text { principů } \\
\end{array}$ \\
\hline Validační & $\begin{array}{l}\text { Vývoj teorie } \\
\text { a/nebo } \\
\text { validace: } \\
\text { vyvíjet } \\
\text { a/nebo } \\
\text { validovat } \\
\text { teorie }\end{array}$ & $\begin{array}{c}\text { Teoretická } \\
\text { kvalita } \\
\text { designu }\end{array}$ & $\begin{array}{l}\text { Iterativní design } \\
\text { s testováním } \\
\text { v malém } \\
\text { měřítku } \\
\text { ve výzkumném } \\
\text { prostředí }\end{array}$ & $\begin{array}{l}\text { 1) Design vzdělávacího } \\
\text { prostředí za účelem } \\
\text { 2) vyvíjet a validovat teorie } \\
\text { o vzdělávání, vzdělávacích } \\
\text { prostředích nebo validovat } \\
\text { konstrukční principy }\end{array}$ \\
\hline
\end{tabular}

Pozn.: Upraveno a doplněno podle Plompa a Nieveenové (2013a, s. 23).

Následující široká a obecnější definice Baraba a Squirea (2004, s. 2) zahrnuje většinu $\mathrm{z}$ výše uvedených variací konstrukčního výzkumu ve vzdělávání: „Konstrukční výzkum není jeden přístup, ale řada přístupů se záměrem vytvořit nové teorie, artefakty a metody, které vysvětlují a potenciálně ovlivňují učení a vyučování v přirozeném prostředí." Pokud do definice konstrukčního výzkumu zahrneme jeho metodologický rámec a dualistický přínos, můžeme ho definovat takto:

Konstrukční výzkum je systematická a flexibilní metodologie zaměřená na zdokonalení vzdělávací praxe prostřednictvím iterativní analýzy, designu, vývoje a implementace vzdělávacích intervencí, založená na aktivní spolupráci výzkumníků, praktiků a žáků v přirozeném prostředí, která vede k produkci konstrukčních principů a nových teorií (Amiel \& Reeves, 2008; Barab \& Squire, 2004; Plomp \& Nieveen, 2013a; Van der Akker, 2006). 


\section{Vývoj a současný stav konstrukčního výzkumu ve vzdělávání}

\subsection{Vznik a vývoj konstrukčního výzkumu}

Konstrukční výzkum byl navržen v roce 1990 americkým výzkumníkem Allanem Collinsem, který upřednostňoval jeho význam pro konstrukční vědy (aeronautika, umělá inteligence) před analytickými vědami (fyzika, psychologie). Collins zdůrazňoval nutnost soustředit se na inovace, které vytváří nejen výzkumníci, ale i praktici. Průkopnicí konstrukčního výzkumu v oblasti pedagogických věd byla Ann Brownová (1992), která ve své výzkumné studii řeší teoretické a metodologické výzvy při vytváření komplexních intervencí $\mathrm{v}$ prostředí třídy a popisuje konstrukční výzkum zaměřený na přeměnu tříd z „akademických pracovních továren“ na učební prostředí, umožňující žákům, učitelům a výzkumníkům reflexi jejich praxe. Brownová (1992) obhajuje kvaziexperimentální metody a zdůvodňuje význam konstrukčního výzkumu pro vývoj nových teorií a hypotéz. Současně ale připouští, že účel jejího výzkumu je pouze informativní. Omezené použití konstrukčního výzkumu bylo také uvedeno ve Zprávě o vědeckých metodách ve vzdělávání Národní výzkumné rady Spojených států amerických (The US National Research Council) $\mathrm{v}$ roce 2002 . V polovině 90 . let 20. století byla Janem Hawkinsem založena skupina Národní sdružení pro konstrukční výzkum (National Design Experiment Consortium), která metodu konstrukčního výzkumu zdokonalila. V roce 1999 založil Christopher Hoadley Design-Based Research Collective financovaný nadací Spencer Foundation. Design-Based Research Collective je malá skupina vědců, kteři se zabývají konstrukčním výzkumem ve vzdělávacím prostředí za podpory různých vzdělávacích technologií. ${ }^{6}$ Jejich snahou je lépe definovat povahu, metody a výsledky konstrukčního výzkumu tak, aby mohli snáze sdílet jejich vlastní výzkum a navázat na práci ostatních. Skupina má tři hlavní cíle:

1) přispět k vývoji metod konstrukčního výzkumu zkoumáním filozofických, epistemologických a praktických důsledků těchto metod s cílem zdokonalit schopnost tohoto výzkumu zapojit se do národního a celosvětového vzdělávacího dialogu;

${ }^{6}$ V anglickém jazyce se termín educational technology používá jak pro praktické využití, tak i jako označení pro teoretický rámec a směr přemýšlení o tom, jak pomocí technologií vhodně vzdělávat, tedy ne pouze pro fyzickou aplikaci technologií do kurikula (Lowenthal \& Wilson, 2010). 
2) zvýšit povědomí o tématech vztahujících se ke konstrukčnímu výzkumu nejen mezi učiteli a pedagogickými výzkumníky, ale i mezi vědci a tvůrci z ostatních společenských věd;

3) zdokonalit vlastní práci v oblasti konstrukčního výzkumu prostřednictvím vzájemné podpory a kritického zhodnocení (Hoadley, 2002).

Metodologii konstrukčního výzkumu se věnovala monotematická čísla následujících časopisů: Educational Researcher (2003/1), Educational Psychologist (2004/4), Journal of the Learning Sciences (2004/2) a Educational Technology (2005/1). V současné době vědci diskutují, zda jsou metody konstrukčního výzkumu primárně užitečné jako výzkumné metody zaměřené na tvorbu artefaktů, nebo zda jsou platné pro testování teorií společenských věd, které jsou závislé na navržených artefaktech nebo intervencích.

Anderson a Shattucková (2011) provedli analýzu 45 článků (studií, recenzí, výzkumných zpráv) s nejvyšším počtem citací o konstrukčním výzkumu, které byly publikovány od roku 2002 do roku 2011, a na tomto základě vyvodili, že zájem o konstrukční výzkum stále roste (srov. obrázek 1) a že jeho metodologie je pro oblast výchovy a vzdělávání velmi př́nosná. Ve své studii se zaměřili na několik oblastí realizace konstrukčního výzkumu ve vzdělávání, ze kterých vybíráme následující oblasti: geografický výskyt, stupeň vzdělávání, vzdělávací program či předmět a použití učebních modelů, metod a strategií.

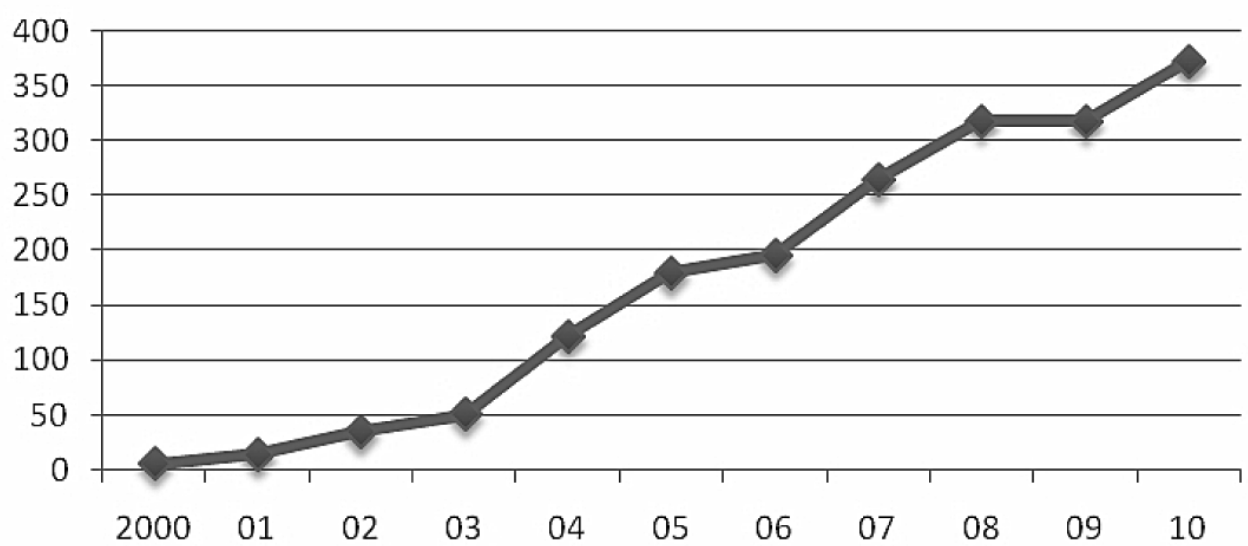

Obrázek 1. Počet článků zabývající se tématem konstrukčního výzkumu. Převzato z Andersona a Shattuckové (2011, s. 19). 


\section{Geografický výskyt}

Tabulka 4 ukazuje, že převaha publikací o konstrukčním výzkumu pochází ze Spojených států amerických, ovšem články byly analyzované na základě země původu autora uvedeného na prvním místě a v některých případech byl článek publikován kolektivem autorů. Anderson a Shattucková (2011, s. 20) zdůvodňují, že „praktická povaha této metodologie vychází z pragmatické tradice americké vzdělávací filozofie založené Deweym a Jamesem“. Druhou zemí, která je aktivní v oblasti realizace konstrukčního výzkumu, je Nizozemsko, kde se touto problematikou zabývá Nizozemský národní institut pro vývoj kurikula (Netherlands Institute for Curriculum Development) v Enschede.

Tabulka 4

Zastoupení zemí zabývajících se konstrukčním výzkumem

\begin{tabular}{lc}
\hline Země & Procentuální zastoupení studií v přehledu \\
\hline Spojené státy americké & $75 \%$ \\
Nizozemsko & $5 \%$ \\
Spojené království & $4 \%$ \\
Singapur & $4 \%$ \\
Švédsko & $2 \%$ \\
Norsko & $2 \%$ \\
Německo & $2 \%$ \\
Kanada & $2 \%$ \\
Tchaj-wan & $2 \%$ \\
Izrael & $2 \%$ \\
Kypr & $2 \%$ \\
\hline
\end{tabular}

Pozn.: Upraveno podle Andersona a Shattuckové (2011, s. 20).

\section{Stupeň vzdělávání}

Veškeré recenzované studie byly realizovány ve vzdělávacím kontextu. Některé články řešily více než jeden předmět, některé studie pracovaly se žáky $\mathrm{z}$ různých stupňů vzdělávání a $\mathrm{v}$ některých př́ípadech nebyl stupeň vzdělávání přesně stanoven, proto se v grafu objevuje nejvyšší procento nespecifikovaného věku či stupně vzdělávání. Přesto je z tabulky 5 zřejmé, že nejčastěji se konstrukční výzkum provádí v postsekundárním vzdělávání. 
Tabulka 5

Výskyt konstrukčního výzkumu v jednotlivých stupních vzdělávání

\begin{tabular}{lc}
\hline Stupeň vzdělávání & Procentuální zastoupení studií v přehledu \\
\hline Nespecifikovaný stupeň/věk & $27 \%$ \\
Postsekundární vzdělávání & $26 \%$ \\
Nižší sekundární vzdělávání & $18 \%$ \\
Primární vzdělávání & $16 \%$ \\
Vyšší sekundární vzdělávání & $13 \%$ \\
\hline
\end{tabular}

Pozn.: Upraveno podle Andersona a Shattuckové(2011, s. 21).

\section{Vzdělávací program/předmět}

Konstrukční výzkum se nejčastěji realizoval v oblasti přírodních věd a v oblasti mezipředmětových vztahů (viz tabulka 6), které převážně zahrnují předmět v kombinaci s výpočetní technikou - vývoj e-learningových portálů, virtuálních prostředí, webových, mobilních a multimediálních aplikací, což vyplývá i z tabulky 8.

Tabulka 6 Výskyt konstrukčního výzkumu v různých oblastech vzdělávání

\begin{tabular}{lc}
\hline Oblasti vzdělávání & Procentuální zastoupení studií v přehledu \\
\hline Př́rodní vědy & $51 \%$ \\
Mezipředmětové vztahy & $13 \%$ \\
Matematika & $9 \%$ \\
Vzdělávání učitelů & $9 \%$ \\
Výpočetní technika & $7 \%$ \\
Anglický jazyk & $5 \%$ \\
Gramotnost & $4 \%$ \\
Odborné vzdělávání & $2 \%$ \\
\hline
\end{tabular}

Pozn.: Upraveno podle Andersona a Shattuckové (2011, s. 22).

\section{Učební modely/metody/strategie}

Mezi nejčastější modely, metody nebo strategie, které současně představují typy intervencí, patř́ integrace různých metod a př́istupů (viz tabulka 7). Na dalším místě se vyskytují učební postupy a autentické učební modely, které se vyskytují i v námi vybraném přehledu studií v tabulce 8 
(např. Bergroth-Koskinen \& Seppälä, 2012; Oh \& Reeves, 2013), a učební postupy.

Tabulka 7

Výskyt výukových modelů/metod/strategií

\begin{tabular}{lc}
\hline Výukové modely/metody/strategie & Procentuální zastoupení studií v přehledu \\
\hline Integrované výukové modely & $40 \%$ \\
Autentické úkoly & $20 \%$ \\
Učební proces & $20 \%$ \\
Kurikulární jednotka & $10 \%$ \\
Strukturovaná podpora „scaffolding“ & $10 \%$ \\
\hline
\end{tabular}

Pozn.: Upraveno podle Andersona a Shattuckové (2011, s. 22).

Výše zmíněný přehled lze doplnit informací o výskytu výzkumných studií na základě hlavních cílů konstrukčního výzkumu ve vzdělávání (Plomp \& Nieveen, 2013b, s. xv), ve kterých měly nejvyšší zastoupení (dvě třetiny ze všech př́ípadů) vývojové studie, čemuž odpovídá i náš přehled v tabulce 8 , a téměř jedna třetina připadla na validační studie zabývající se vývojem teorie. Zbytek připadl na validační studie zaměřené na validaci teorie a implementační studie zaměřené na implementaci vzdělávacích intervencí.

\subsection{Přehledová studie konstrukčních výzkumů}

Pro analýzu dosavadního stavu poznání v oblasti konstrukčního výzkumu ve vzdělávání jsme zpracovali přehledovou studii (viz tabulka 8) na základě pěti aspektů každého $\mathrm{z}$ realizovaných výzkumů vycházejících z následujících otázek:

- Jak je konstrukční výzkum konceptualizován a na jakém vzdělávacím stupni probíhal?

- Jaké cíle jsou v konkrétním konstrukčním výzkumu stanoveny?

- Jaký typ intervence je v rámci konstrukčního výzkumu realizován?

- Jaké př́stupy, metody a nástroje jsou použity a na jakých výzkumných souborech?

- Jaké jsou závěry, popř. doporučení daného konstrukčního výzkumu?

Pro výběr studií zabývajících se konstrukčním výzkumem ve vzdělávání bylo provedeno vyhledávání v databázích ERIC, EBSCO, Web of Science a Wiley 
Online Library, které obsahují spolehlivé zdroje (renomované časopisy, sborníky, knihy apod.) z oblasti pedagogického výzkumu a metodologie výuky cizích jazyků. Vyhledávána byla slovní spojení „design-based research“, „educational design research“ a „English learning materials development“. Velké množství studií ve výše zmíněných databázích řeší spíše teoretická východiska a obecnou metodologii konstrukčního výzkumu. Studií, které se věnují praktické a systematické realizaci konstrukčního výzkumu s uvedením konkrétní metodologie a podrobnějšího vymezení výzkumných souborů, je poněkud menší počet. $Z$ celkového souboru 74 studií, publikovaných od roku 1992 do roku 2016, bylo v konečné fázi vybráno pouze 13 studií, které splňovaly kritéria našeho výběru, tzn. zaměřují se na design učebních materiálů a/ nebo výuku jazyků. Vzhledem $\mathrm{k}$ tomu, že některé výzkumy využívaly integrované výukové modely s využitím informačních technologií, byly do přehledu zařazeny i tyto typy studií.

V České republice byly dosud publikovány pouze tři studie věnující se konstrukčnímu výzkumu ve vzdělávání, z nichž dvě se orientují na tvorbu učebních materiálů (učebnice a pracovní listy), a přestože nebyly tyto výzkumy zcela dokončeny, mají v naší přehledové studii svoje místo z toho důvodu, že pro nás představují výzvu pro zrealizování našeho konstrukčního výzkumu. Dvořák, Dvořáková a Stará (2008) ve studii podávají obecný přehled vývoje myšlenky výzkumné strategie konstrukčního výzkumu a projekt aplikace této strategie $\mathrm{v}$ rámci tvorby nových učebnic prvouky a vlastivědy. $V$ závěru své práce si realizátoři výzkumu kladou za cíl zaměřit se na změny v obsahu učebnice (zastoupení témat, nová témata, doporučované typy činností), změny v metodách prezentace učiva (poměr textu a grafiky, typ ilustrací, poměr fotografií a ilustrací apod.), inovace v doprovodných materiálech a ve způsobu užívání (pojetí příručky učitele). Současně zamýšlí dále rozvíjet teoretické a metodologické základy strategie konstrukčního výzkumu.

Trna (2011) si ve své teoretické studii s praktickou ukázkou žákovského experimentu ve formě pracovních listů pro žáky základní školy na téma Aplikace fyziky v každodenním životě klade za cíl prezentovat studii konstrukčního výzkumu jako vstup do širší diskuze v přírodovědných didaktikách. V závěru své studie zdůrazňuje nutnost podrobnějšího popisu vlastní metody konstrukčního výzkumu s jeho historickým vývojem a zasazením do systému metodologie př́rodovědných didaktik. Rovněž ve své studii navrhuje řadu dalších výzkumných problémů, které by se v souvislosti s konstrukčním výzkumem daly řešit, jako např. propojení konstrukčního výzkumu a praxe, vazba aktuálního paradigmatu přírodovědných didaktik a konstrukčního výzkumu, vztah 
konstrukčního a akčního výzkumu, zařazení prvků konstrukčního výzkumu do přípravného i dalšího vzdělávání učitelů přírodovědných předmětů.

Studie Chvála a kol. (2008) není v přehledu studií zařazena, protože její téma nesplňuje kritéria našeho výběru, nicméně bychom zde rádi tento výzkum nastínili. Jejich konstrukční výzkum byl uskutečněn při realizaci jedné komponenty programu podpory rozvoje škol, kterou byly pobytové semináře pro učitele. Cílem bylo vytvořit a postupně upravit určitý typ výjezdní vzdělávací akce do podoby, která nesleví z hlavních vzdělávacích cílů a současně bude učiteli pozitivně přijímána, a následně z průběžné a strukturované reflexe přípravy, průběhu a vyhodnocení vzdělávacích akcí vytěžit poznatky o př́činách bariér mezi pedagogickou vědou a praxí na školách a o možnostech jejich odstraňování. Výsledky jejich konstrukčního výzkumu potvrdily potřebu specialistů-designérů, kteří se budou zaměřovat na šíření výsledků výzkumu do praxe prostřednictvím hotových, výzkumem podložených produktů povahy materiální (např. učebnice) nebo nemateriální (např. vytváření vzdělávacích akcí). Kolektiv výzkumníků rovněž potvrdil, že empirickými daty a reflexí podloženým iterativním re-designem konkrétního produktu lze dosáhnout „Zvýšení spokojenosti účastníků a vnímané užitečnosti odborných témat" (Chvál et al., 2008, s. 123).

Výsledky analýzy studí́ jsou rozděleny na základě pěti aspektů každého z realizovaných konstrukčních výzkumů, kterými jsou koncept a cíle výzkumu, typ intervence, výzkumná metodologie a výsledky výzkumu (srov. tabulka 8).

Koncept výzkumu

Koncept výzkumu v analyzovaných studiích lze rozdělit do tří skupin, přičemž některé realizované výzkumy spadají do více skupin:

- vývoj učebních materiálů pro výuku (Baumann et al., 2013; BergrothKoskinen \& Seppälä, 2012; Dvořák et al., 2008; Ozverir, Herrington, \& Osam, 2016; Palalas \& Anderson, 2013; Pardo-Ballester \& Rodríguez, 2010; Trna, 2011),

- vývoj výukových metod (Ivey, 2013),

- kombinace vývoje informačních technologií a vývoje učebních materiálů, vyučovacích metod a hodnocení (Baumann et al., 2013; Klopfer \& Squire, 2007; Liu, Liu, \& Hwang, 2011; Nieveen, 2013; Oh \& Reeves, 2013; Ozverir et al., 2016; Palalas \& Anderson, 2013; Pardo-Ballester \& Rodríguez, 2010; Thomas, Barab, \& Tüzün, 2009). 


\section{Cíle výzkumu}

Cíle výzkumu analyzovaných studií se převážně zaměřují na vývojovou analýzu učebních materiálů, výukových a učebních metod, evaluačních kritérií, mobilních aplikací, multimediálního projektu; inovativní intervenci, at' už prostřednictvím softwarové aplikace, e-learningového portálu, tištěných učebních materiálů či výukové metody a vývoj konstrukčních principů.

\section{Typ intervence}

Na základě typu intervence lze analyzované studie rozdělit do tř́ skupin:

- vzdělávací program a kurikulum (Baumann et al., 2013; Dvořák et al., 2008; Klopfer \& Squire, 2007; Thomas et al., 2009; Trna, 2011);

- kurikulární jednotka, kurz, popř. modul (Bergroth-Koskinen \& Seppälä, 2012; Liu et al., 2011; Nieveen, 2013; Oh \& Reeves, 2013; Ozverir et al., 2016; Palalas \& Anderson, 2013; Pardo-Ballester \& Rodríguez, 2010);

- $\quad$ autentické úkoly (Bergroth-Koskinen \& Seppälä, 2012; Ivey, 2013; Klopfer \& Squire, 2007; Oh \& Reeves, 2013; Palalas \& Anderson, 2013).

\section{Výzkumná metodologie}

Výzkumy byly realizované na různě velkých výzkumných souborech. Největší soubor, na kterém byl výzkum realizován, tvořilo 606 žáků základní školy ve studii Baumanna a kol. (2013); v ostatních případech se nejčastěji počet pohyboval kolem 100 žáků/studentů základních, středních a vysokých škol. Další soubory tvořili učitelé, jejichž počet se pohyboval v rozmezí 1-15 učitelů. $V$ jednom př́padě studie pracovala se 75 rodiči žáků (Trna, 2011) a v jednom př́padě představoval výzkumný soubor tým 17 výzkumníků z Nizozemského národního institutu pro vývoj kurikula (SLO).

Všechny realizované výzkumy v námi analyzovaných studiích používaly kombinaci různých kvantitativních i kvalitativních metod. Počet použitých metod se nejčastěji pohyboval v rozmezí tři až čtyř metod. Mezi nejčastější uváděné metody sběru dat patřila dotazníková šetření ( $\mathrm{v}$ devíti studiích), rozhovory (v osmi studiích) a pozorování (v sedmi studiích). Mezi dalšími uvedenými metodami sběru dat byly videozáznamy, analýza produktů žáků/studentů, reflektivních deníků učitelů a dokumentů, didaktické testy a v jednom př́padě bylo jako metoda sběru dat použito nahrávání interakce studentů s texty a glosami prostřednictvím počítačové aplikace Camtasia Studio. Mezi designy 
použitého kvalitativního výzkumu byly uvedeny případové studie (Klopfer \& Squire, 2007; Oh \& Reeves, 2013; Thomas et al., 2009) a etnografické studie (Bergroth-Koskinen \& Seppälä, 2012).

\section{Výsledky výzkumu}

Všechny analyzované studie (viz tabulka 8) potvrzují skutečnost, že konstrukční výzkum vede ke třem hlavním výsledkům (viz obrázek 2 ): k produkci konstrukčních principů, které přináší nové znalosti obohacující daný obor, ke kurikulárním produktům, které přispívají pedagogické praxi v místním i globálním rámci, a k profesnímu vývoji účastníků.

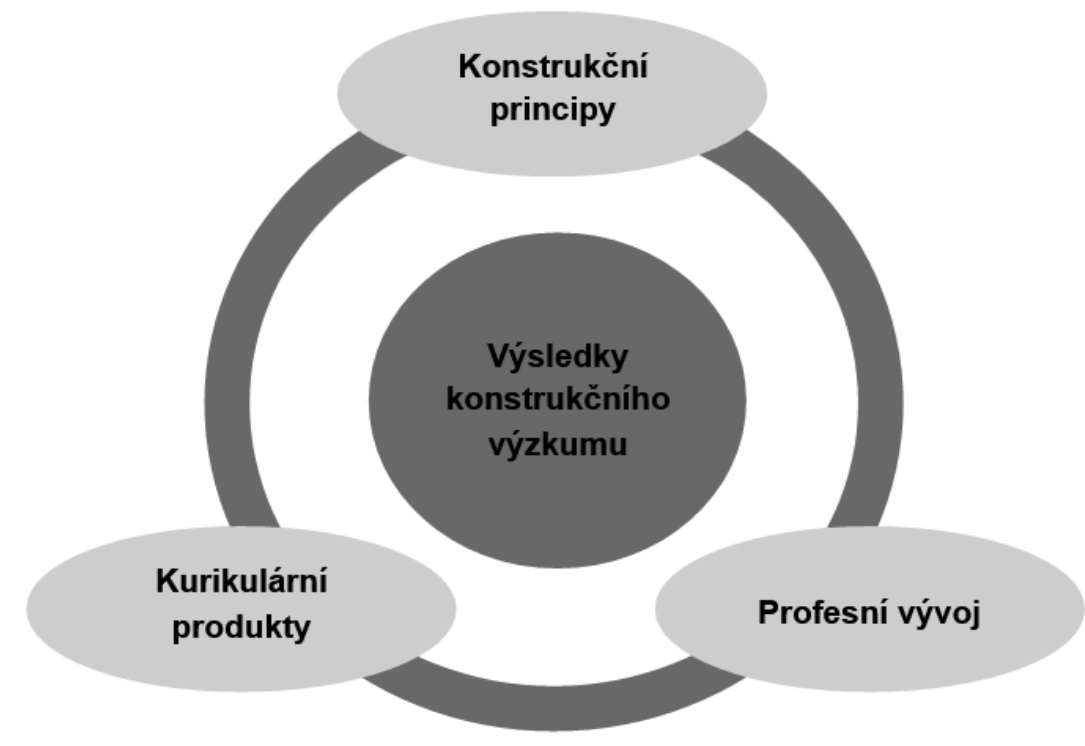

Obrázek 2. Tři výsledky konstrukčního výzkumu ve vzdělávání. Upraveno podle Ohové a Reevese (2013, s. 1006).

Jako př́iklady konkrétních konstrukčních principů vyplývajících z analyzovaných studií lze např́klad uvést ty, které se týkají skupinové spolupráce při hodnocení učebních materiálů (Nieveen, 2013; Oh \& Reeves, 2013): (a) posílit pocit sounáležitosti, (b) podpořit individuální motivaci a zapojení se, (c) maximalizovat výhody spolupráce, (d) podpořit individuální odpovědnost ve skupinových projektech a (e) poskytnout studentům různé technologie, které mohou plně využít. Palalasová a Anderson (2013, s. 972) uvádějí tři konstrukční principy pro jejich systém MELLES pro výuku jazyka: (a) odvodit základní charakteristiku systému z prototypů a procesu jejich hodnocení, (b) popsat strategii pro design systému a (c) zdůvodnit význam systému. 


\section{„Bílá místa“ v realizovaných výzkumech}

$\mathrm{V}$ analyzovaném přehledu konstrukčních výzkumů je možné identifikovat určitá „bílá místa“, která představují východiska pro téma našeho výzkumu. Především zde chybí realizace systematického konstrukčního výzkumu učebnic, které mají prvořadé místo mezi materiálními didaktickými prostředky. Pouze dvě studie se zaměřovaly na oblast vývoje učebních materiálů pro cizojazyčnou výuku:

- vývoj učebních materiálů pro kurzy španělštiny (Pardo-Ballester \& Rodríguez, 2010), které se zaměřovaly pouze na rozvoj dovedností v oblasti čtení, avšak ostatní receptivní a produktivní dovednosti nebyly předmětem výzkumu;

- design kurzu akademické angličtiny (Bergroth-Koskinen \& Seppälä, 2012), ve kterém byly analyzované učební materiály pouze ve formě zadání různých úloh a powerpointových prezentací, avšak studie neuvádí produkci konkrétních konstrukčních principů v této oblasti.

Vzhledem k tomu, že zejména učitelé ESP musí často vytvářet vlastní učební materiály tak, aby co nejlépe vyhovovaly potřebám cílové skupiny studentů a časově omezenému kurzu, může pro ně být vývoj designu učebních materiálů prostřednictvím konstrukčního výzkumu žádoucí. V procesu konstrukčního výzkumu učebnice ESP je možné využít různé metody hodnocení učebnic, více např. Hutchinson a Waters (1987), Cunningsworth (1995), Mikk (2007), Sikorová (2007), McDonoughová, Shaw a Masuharová (2013) a Barnard a Zemachová (2014). Z uvedené analýzy studií vyplývá, že konstrukční výzkum učebnic a učebních materiálů pro výuku cizích jazyků je spíše okrajovým jevem a výše zmíněné deficity představují východiska pro náš vlastní výzkum učebnice pro výuku ESP.

\section{Závěry a doporučení}

Konstrukční výzkum představuje výzvu pro všechny výzkumníky a praktiky, kteří usilují o překlenutí mezery mezi výzkumem a praxí prostřednictvím rozvoje poznatků systematicky získaných v praxi. Hlavní argumenty pro realizaci konstrukčního výzkumu pramení ze snahy posílit relevanci a spolehlivost výzkumu pro vzdělávací politiku a pedagogickou praxi a z vývoje empiricky zakotvených teorií prostřednictvím analýzy vzdělávacího procesu a prostředků, které tento proces podporují. Mezi důležité faktory vyplývající 
z námi analyzovaných studií patří pozitivní prínos intervence, význam participace žáků na vývoji designu intervence a spolupráce mezi výzkumníky a praktiky.

Intervence u realizovaných výzkumů vedou ke zlepšení výsledků a přístupů žáků ke studiu a analyzované studie nám nabízí důležitá vodítka týkající se vzájemného souladu mezi úspěšným testováním intervence a praktickým kontextem. Podle Iveyové (2013, s. 247) jsou př́nosem intervence z výzkumného pohledu „teoretické výsledky vyplývající ze změn, které se odehrávaly ve tř́́dách spolu s nezáměrnými pozitivními účinky intervence a změnami ve vzdělávacím prostředí“. Palalasová a Anderson (2013, s. 986) uvádí, že hlavním měřítkem úspěchu pokroku a úspěchu konstrukčního výzkumu ve vzdělávání je intervence, která vyhovuje potřebám účastníků.

Realizované konstrukční výzkumy poskytují přínosný vhled do vzájemné interakce a vztahu mezi žáky a učebními materiály. Přístupy a názory žáků jsou důležitou součástí procesu tvorby učebních materiálů, protože vedou nejen ke zlepšení efektivního využití materiálů, ale také posunou jejich vývoj směrem k obohacení procesu učení. Pardo-Ballesterová a Rodríguez (2010, s. 551) potvrzují, že vnímání žákủ hraje klíčovou roli v postupném zhmotnění představ výzkumníků a praktiků. Rovněž Iveyová (2013, s. 247) zdůrazňuje, že postoje žáků k důsledkům jejich zapojení ukazují nejen pokrok v oblasti učení, ale i společenský, emoční, morální a individuální vývoj. V případě využití informačních technologií se doporučuje, aby designéři vzdělávacího softwaru vytvářeli aplikace tak, aby učitelé i žáci měli možnost přizpůsobit si vzdělávací prostředí (Klopfer \& Squire, 2007).

Úzká spolupráce a komunikace mezi žáky, praktiky a výzkumníky po dobu celého výzkumu jsou nezbytnou podmínkou pro úspěšnou realizaci a dokončení výzkumu. Pevná koordinace mnoha aktivit, nadšení účastníků a neustálá komunikace jsou „tmelem“ konstrukčního výzkumu ve vzdělávání (Palalas \& Anderson, 2013, s. 986). „Intervenci vytvořenou ve spolupráci s praktiky a výzkumníky by nebylo možné uskutečnit vně výzkumného modelu [...] synergie efektivního spolupưsobení byla téměř hmatatelná“ (Baumann et al., 2013, s. 39).

\subsection{Doporučení pro výzkumný záměr}

Z výsledků realizovaných konstrukčních výzkumů vyplývá několik doporučení pro náš výzkumný záměr. Průběžná (formativní) evaluace a dokumentace 
všech změn realizovaných na designu směřující ke zdokonalení je nezbytnou součástí všech fází a iterativních cyklů. Existuje několik metod průběžné evaluace, majících své výhody i možné nedostatky (Plomp \& Nieveen, 2013a, s. 35), které je vhodné zařadit v následujících fázích:

1) Sebehodnocení (s využitím seznamu hodnoticích kritérií „checklistu“), které ovšem může vést ke zjevným chybám v důsledku subjektivního postoje samotného autora designu.

2) Individuální „one-to-one“ evaluace (s pomocí představitele cílové skupiny) zajistí užitečnou zpětnou vazbu o kvalitě designu a jeho vlivu na proces učení, ale opět může vést ke zjevným chybám v důsledku subjektivity.

3) Odborný přezkum a/nebo specializované skupiny (je důležité zvážit, o jaké odborníky a v jakém oboru se jedná) ověří obsahovou a technickou kvalitu a kvalitu designu.

4) Evaluace v malé skupině ověřuje efektivnost a proveditelnost.

5) Provozní zkouška ověří proveditelnost a uživatelskou a organizační přijatelnost.

Dalším důležitým doporučením je prověrení udržitelnosti, prenenosnosti a zobecnitelnosti výsledků výzkumu jak v místních, tak v širších kontextech (Oh \& Reeves, 2013, s. 1008). Výzkumníci by tedy měli usilovat o aplikaci a testování řešení a konstrukčních principů $\mathrm{v}$ různých prostředích a v širších doménách. Zobecnění konstrukčních principů ovšem není automatické, je nutné je testovat prostřednictvím replikovaných zjištění ve třech či více případech $\mathrm{v}$ různých kontextech s cílem dosažení stejných výsledků. Jedině takovým způsobem mohou být výsledky přijatelné pro větší množství podobných kontextů. Plomp a Nieveenová (2013a) hovoří o tzv. „replikační logice“, která je základem využívání experimentů a umožňuje výzkumníkům provádět zobecnění $z$ jednoho experimentu na další. Je ovšem nutné mít na paměti, že „každý kontext má jedinečné charakteristiky, které ospravedlňují použití konstrukčních principů jako ,heuristických tvrzení', která poskytují návod a směr, ale nezaručují ,jistoty“" (Plomp \& Nieveen, 2013, s. 34). Jakékoli zobecnění v konstrukčním výzkumu tedy představuje spíše hypotézu, než konkrétní závěr. 


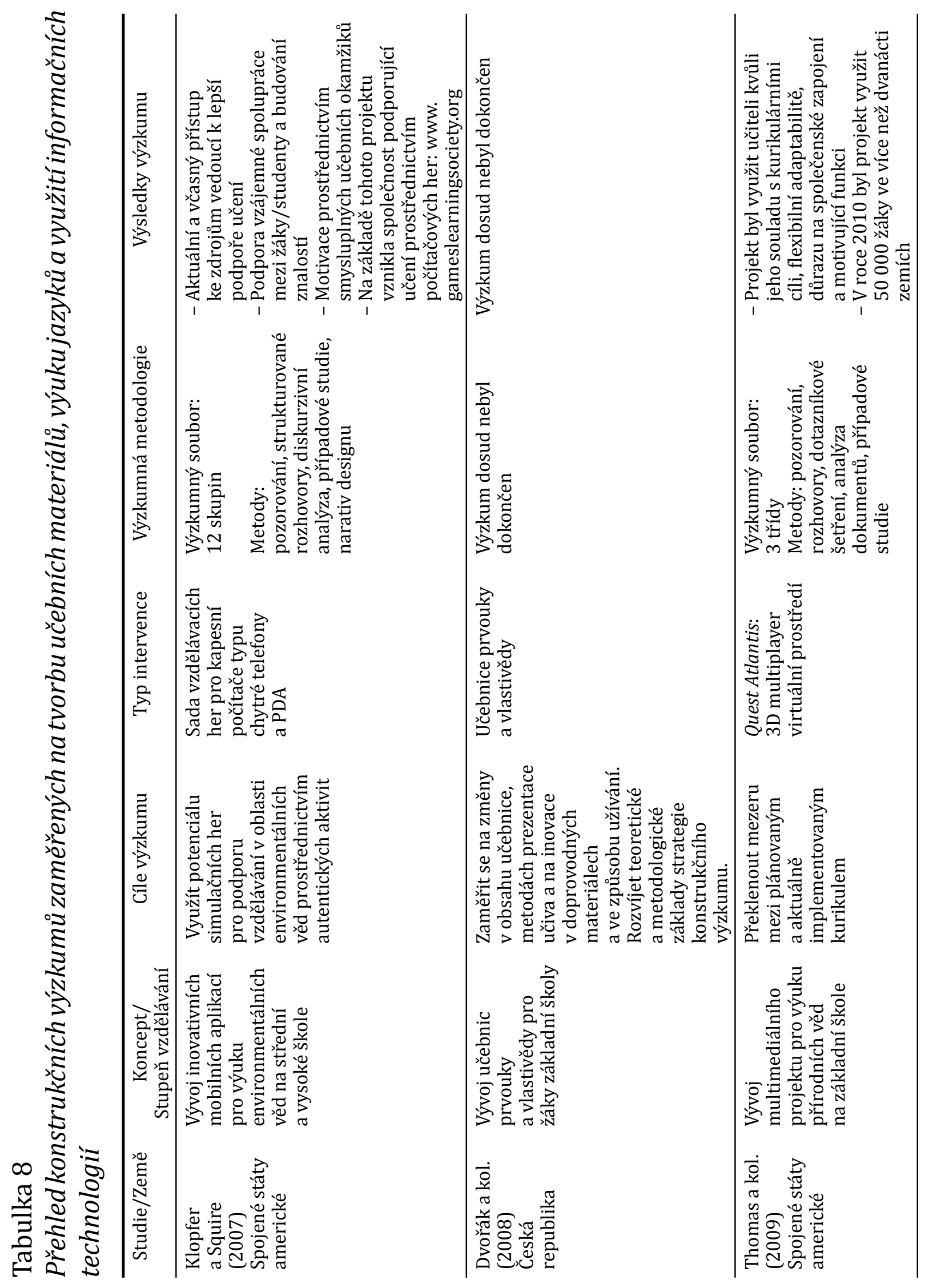




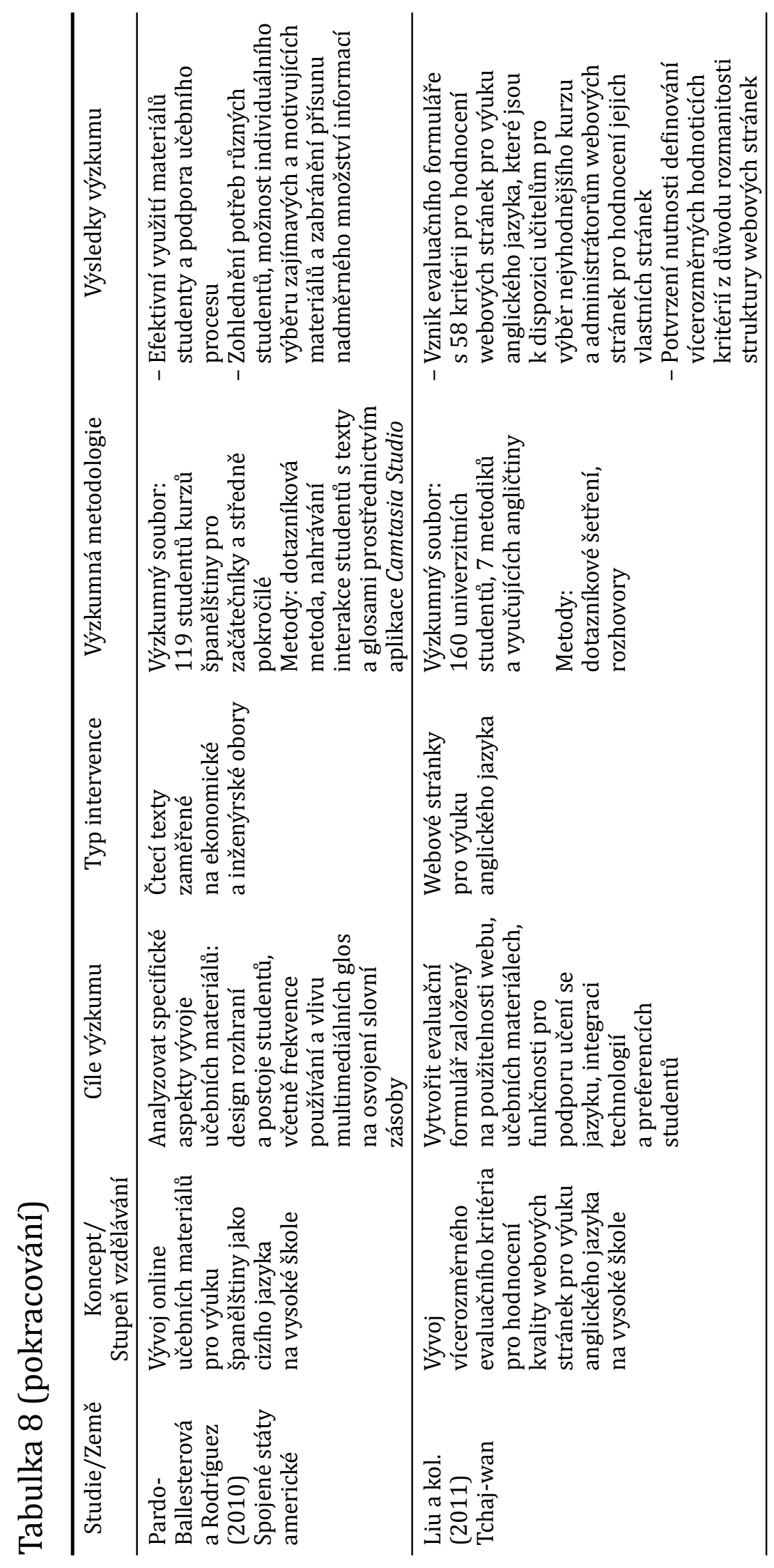




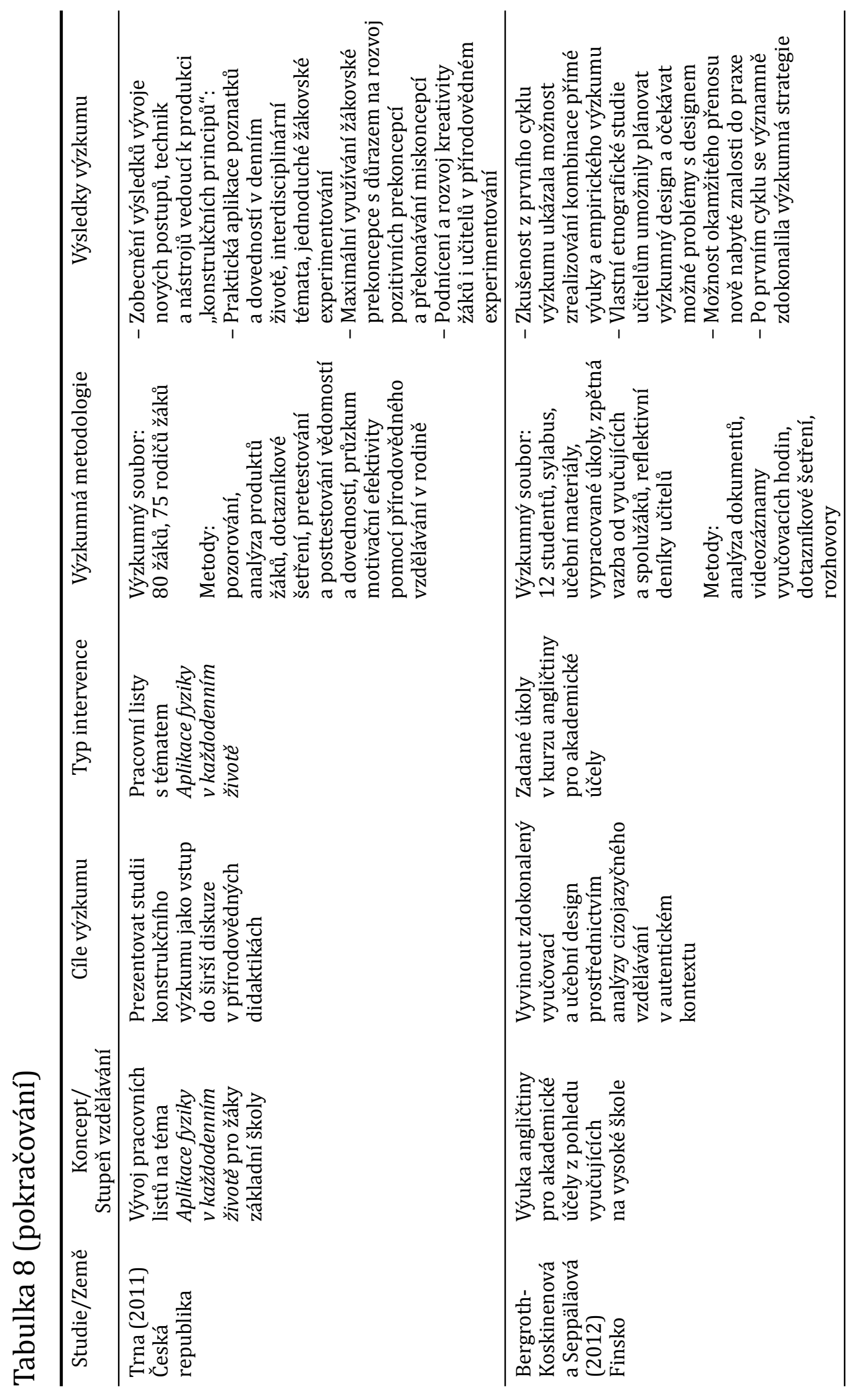




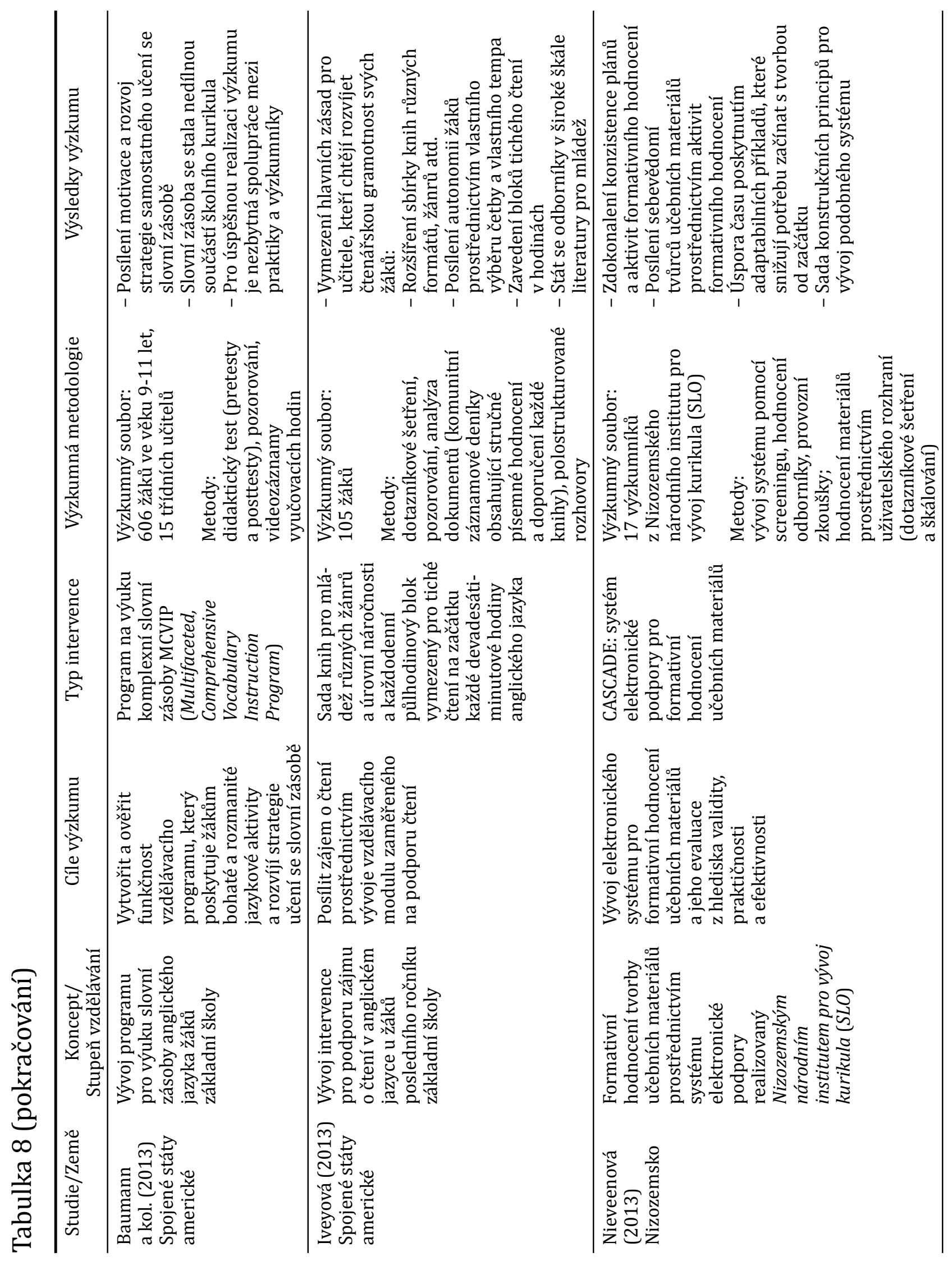




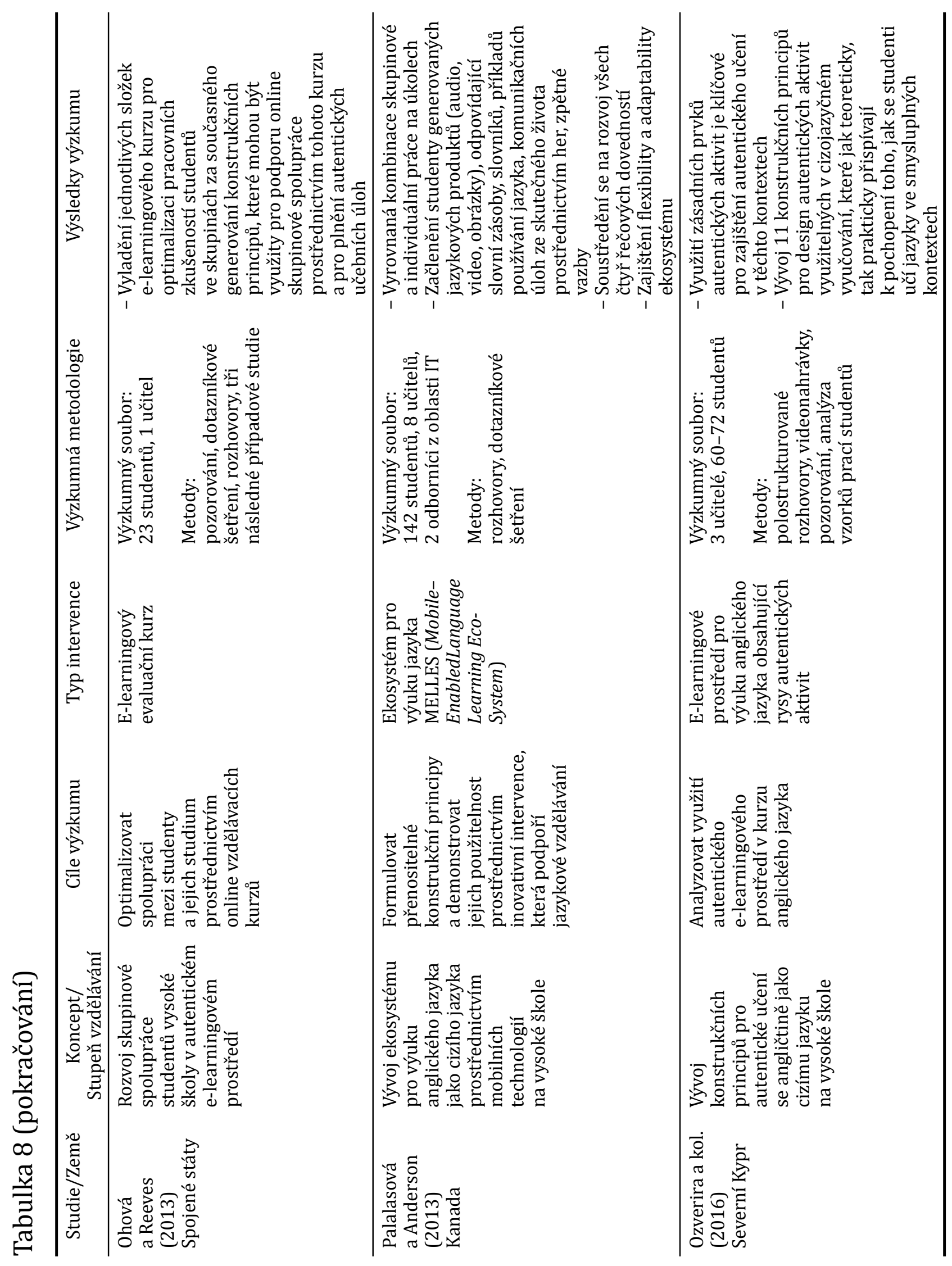




\section{Literatura}

Amiel, T., \& Reeves, T. C. (2008). Design-based research and educational technology: Rethinking technology and the research agenda. Educational Technology \& Society, 11(4), 29-40.

Anderson, T., \& Shattuck, J. (2011). Design-based research: A decade of progress in education research? Educational Researcher, 41(1), 16-25.

Bakker, A., \& Van Eerde, H. A. A. (2013). An introduction to design based research with an example from statistics education. In A. Bikner-Ahsbahs, C. Knipping, \& N. Presmeg (Eds.), Doing qualitative research: Methodology and methods in mathematics education (s. 429-466). New York: Springer.

Barab, S., \& Squire, K. (2004). Design-based research: Putting a stake in the ground. Journal of the Learning Sciences, 13(1), 1-14.

Barnard, R., \& Zemach, D. (2014). Materials for specific purposes. In B. Tomlinson (Ed.), Developing materials for language teaching (s. 306-323). London: Bloomsbury.

Baumann, J., Blachowicz, C., Bates, A., Cieply, C., Manyak, P., Peterson, H., \& Graves, M. (2013). The development of a comprehensive vocabulary instruction program for nine- to eleven-year-old children using a design experiment approach. In T. Plomp \& N. Nieveen (Eds.), Educational design research. Part B: Illustrative cases (s. 23-47). Enschede: SLO Netherlands Institute for Curriculum Development.

Bergroth-Koskinen, U. M., \& Seppälä, R. (2012). Teacher-researchers exploring design-based research to develop learning designs in higher education language training. Apples Journal of Applied Language Studies, 6(2), 95-112.

Brown, A. L. (1992). Design experiments: Theoretical and methodological challenges in creating complex interventions in classroom settings. Journal of the Learning Sciences, 2(2), 141-178.

Cobb, P., Confrey, J., DiSessa, A., Lehrer, R., \& Schauble, L. (2003). Design experiments in educational research. Educational Researcher, 32(1), 9-13.

Collins, A. (1990). Towards a design science of education. New York: Center for Technology in Education.

Collins, A., Joseph D., \& Bielaczyc, K. (2004). Design research: Theoretical and methodological issues. Journal of the Learning Sciences, 13(2), 15-42.

Cunningsworth, A. (1995). Choosing your coursebook. Oxford: Macmillan.

Design-Based Research Collective. (2003). Design-based research: An emerging paradigm for educational inquiry. Educational Researcher, 32(1), 5-8.

DiSessa, A. A., \& Cobb, P. (2004). Ontological innovation and the role of theory in design experiments. The Journal of the Learning Sciences, 13(1), 77-103.

Dvořák, D., Dvořáková, M., \& Stará, J. (2008). Design-based research - výzkum učebnic prováděných jejich tvůrci. In P. Knecht \& T. Janík, et al., Učebnice z pohledu pedagogického výzkumu (s. 81-89). Brno: Paido.

Hoadley, C. (2002). Creating context: Design-based research in creating and understanding CSCL. In G. Stahl (Ed.), Computer support for collaborative learning (s. 453-462). Mahwah: Lawrence Erlbaum Associates.

Hogue, R. J. (2013). Epistemological foundations of educational design research. In T. Bastiaens \& G. Marks (Eds.), Proceedings of E-Learn 2013 - World Conference on E-Learning in Corporate, Government, Healthcare, and Higher Education (s. 1915-1922). Las Vegas: Association for the Advancement of Computing in Education (AACE).

Hutchinson, T., \& Waters, A. (1987). English for specific purposes. A learning-centred approach. Cambridge: Cambridge University Press. 
Chvál, M., Dvořák, D., Starý, K., \& Marková, K. (2008). Design-based research při hledání cest dalšího vzdělávání učitelů. Orbis Scholae, 2(3), 107-130.

Ivey, G. (2013). Developing an intervention to increase engaged reading among adolescents. In T. Plomp \& N. Nieveen (Eds.), Educational design research. Part A: Illustrative cases (s. 235-251). Enschede: SLO - Netherlands Institute for Curriculum Development.

Kelly, A., Lesh, R., \& Baek, J. (Eds.). (2008). Handbook of design research methods in education. New York: Routledge.

Klopfer, E., \& Squire, E. (2007). Environmental detectives - the development of an augmented reality platform for environmental simulations. Educational Technology Research and Development, 56(2), 203-228.

Lijnse, P. (2010). "Developmental research" as a way to an empirically based "didactical structure" of science. In K. Kortland \& K. Klaasen (Eds.), Designing theory-based teachinglearning sequences for science education (s. 91-102). Utrecht: FIsme.

Liu, G. Z., Liu, Z. H., \& Hwang, G. J. (2011). Developing multi-dimensional evaluation criteria for English learning websites with university students and professors. Computers \& Education, 56(1), 65-79.

Lowenthal, P. R., \& Wilson, B. G. (2010). Labels do matter! A critique of AECT's redefinition of the field. TechTrends 54(1), 38-46.

McDonough, J., Shaw, C., \& Masuhara, H. (2013). Materials and methods in ELT. A teacher's guide. Chichester: Wiley-Blackwell.

Mikk, J. (2007). Učebnice: budoucnost národa. In P. Knecht \& J. Maňák (Eds.), Hodnocení učebnic (s. 31-39). Brno: Paido.

Newman, D. (1990). Opportunities for research on the organizational impact of school computers. Educational Researcher, 19(3), 8-13.

Nieveen, N. (2013). A four-year design research study improving curriculum developers' formative evaluation through an electronic performance support system. In T. Plomp \& N. Nieveen (Eds.), Educational design research. Part B: Illustrative cases (s. 1101-1123). Enschede: SLO - Netherlands Institute for Curriculum Development.

Oh, E. G., \& Reeves, T. (2013). Collaborative group work in an online authentic learning environment: An educational design research study. In T. Plomp \& N. Nieveen (Eds.), Educational design research. Part B: Illustrative cases (s. 991-1012). Enschede: SLO Netherlands Institute for Curriculum Development.

Ozverir, I., Herrington, J., \& Osam, U. V. (2016). Design principles for authentic learning of English as a foreign language. British Journal of Educational Technology, 47(3), 484-493.

Palalas, A., \& Anderson, T. (2013). Educational design research: Designing mobile learning interventions for language learners. In T. Plomp \& N. Nieveen (Eds.), Educational design research. Part B: Illustrative cases (s. 967-989). Enschede: SLO - Netherlands Institute for Curriculum Development.

Pardo-Ballester, C., \& Rodríguez, J. C. (2010). Developing Spanish online readings using designbased research. CALICO Journal, 27(3), 540-553.

Plomp, T., \& Nieveen, N. (Eds.). (2007). An introduction to educational design research. Enschede: SLO - Netherlands Institute for Curriculum Development.

Plomp, T., \& Nieveen, N. (Eds.). (2013a). Educational design research. Part A: An Introduction. Enschede: SLO - Netherlands Institute for Curriculum Development.

Plomp, T., \& Nieveen, N. (Eds.). (2013b). Educational design research. Part B: Illustrative cases. Enschede: SLO - Netherlands Institute for Curriculum Development.

Reeves, T. C., McKenney, S., \& Herrington, J. (2011). Publishing and perishing: The critical importance of educational design research. Australasian Journal of Educational Technology, $27(1), 55-65$. 
Shulman, L. S. (1987). Knowledge and teaching: Foundations of the new reform. Harvard Educational Review, 57(1), 1-22.

Sikorová, Z. (2007). Návrh seznamu hodnotících kritérií pro učebnice základních a středních škol. In P. Knecht \& J. Maňák (Eds.), Hodnocení učebnic (s. 31-39). Brno: Paido.

Štemberger, T., \& Cencič, M. (2014). Design-based research in an educational context. Journal of Contemporary Educational Studies, 1, 62-72.

Thomas, M. K., Barab, S. A., \& Tüzün, H. (2009). Developing critical implementations of technology-rich innovations: A cross-case study of the implementation of Quest Atlantis. Journal of Educational Computing Research, 41(2), 125-153.

Trna, J. (2011). Konstrukční výzkum v přírodovědných praktikách. Scientia in Educatione, 2(1), 3-14.

Van der Akker, J. (Ed.). (2006). Educational design research. Abingdon: Routledge.

Višňovský, E., Kaščák, O., \& Pupala, B. (2012). Pedagogický dualizmus teoretického a praktického: historické pozadie a súčasné ilúzie. Pedagogická orientace, 22(3), 305-335.

\section{Autorka}

Mgr. Ing. Eva Ellederová, Masarykova univerzita, Pedagogická fakulta, Institut výzkumu školního vzdělávání, Poříčí 31, 60300 Brno, e-mail: elleva@seznam.cz

\section{Educational design research}

Abstract: The aim of this study is to frame the concept of educational design research as a research design, which puts emphasis on the development of research-based solutions to complex problems in educational practice and development or validation of theories about learning processes and learning environments. To illustrate the importance of educational design research, we discuss its open and interventionist nature and twofold yield. Next, this study traces the origins, development and current state of educational design research, which at the beginning of the $21^{\text {st }}$ century launched a new stage in practical research methodology aiming to bridge the gap between research and practice in formal education. The study provides a representation of educational design research in selected countries, educational sectors and types of intervention. The core of this study is a survey of illustrative cases of design research focusing on design of learning materials and language education. Based on the analysis of empirical studies, we discuss important factors and recommendations that provide theoretical and methodological background for our design research of a textbook for English for specific purposes.

Keywords: design research, intervention, iteration, experimental research, action research, twofold yield of design research, validation and development studies, procedural and substantive design principles, didactic reconstruction 